\begin{tabular}{|l|l|l||}
\hline \multicolumn{2}{|c|}{ PublisherInfo } \\
\hline \hline PublisherName & $:$ & BioMed Central \\
\hline \hline PublisherLocation & $:$ & London \\
\hline \hline PublisherImprintName & $:$ & BioMed Central \\
\hline \hline
\end{tabular}

\title{
Sticky switches
}

\begin{tabular}{|l|l|l||}
\hline \multicolumn{2}{|c|}{ ArticleInfo } \\
\hline \hline ArticleID & $:$ & 3705 \\
\hline \hline ArticleDOI & $:$ & $10.1186 /$ gb-spotlight-20000621-02 \\
\hline \hline ArticleCitationID & $:$ & spotlight-20000621-02 \\
\hline \hline ArticleSequenceNumber & $:$ & 142 \\
\hline \hline ArticleCategory & $:$ & Research news \\
\hline \hline ArticleFirstPage & $:$ & 1 \\
\hline \hline ArticleLastPage & $:$ & 2 \\
\hline \hline & & RegistrationDate : 2000-06-21 \\
ArticleHistory & $:$ & OnlineDate $\quad$ 2000-06-21 \\
\hline \hline ArticleCopyright & $:$ & BioMed Central Ltd2000 \\
\hline \hline ArticleGrants & $:$ & \\
\hline \hline ArticleContext & $:$ & 130591111 \\
\hline \hline
\end{tabular}




\section{William Wells}

Email: wells@biotext.com

The binding interface between human growth hormone $(\mathrm{hGH})$ and the hGH receptor has a welldefined hydrophobic core. In the 16 June Science, Guo et al. replace two residues from this region (a threonine from hGH and a tryptophan from the hGH receptor) with glycines to create a cavity. They then screen a library of around 200 indole-based compounds and find one that can restore the binding of the two mutated proteins (Science 2000, 288:2042-2045). The 1000-fold increase in binding affinity in the presence of the chemical constitutes a switch that may ultimately find applications in vivo.

\section{References}

1. A hot spot of binding energy in a hormone-receptor interface.

2. Science magazine, [http://www.sciencemag.org/] 